УДК 658:[005.32+005.73]

https://doi.org/10.52058/2708-7530-2021-12(18)-493-504

Федоров Олександр Володимирович кандидат педагогічних наук, доцент кафедри психології та соціально-гуманітарних дисциплін, Центральноукраїнський інститут Приватного акціонерного товариства «Вищий навчальний заклад «Міжрегіональна Академія управління персоналом», вул. Варшавська, 2, м. Кропивницький, 25026, тел.: (095) 901-85-74, e-mail: fov.1961@ukr.net, https://orcid.org/0000-0002-0458-3587

Подоляка Анатолій Миколайович доктор юридичних наук, професор кафедри правознавства, Центральноукраїнський інститут Приватного акціонерного товариства «Вищий навчальний заклад «Міжрегіональна академія управління персоналом», вул. Варшавська, 2, м. Кропивницький, 25026, тел.: (067) 442-00-05, e-mail: tdp413@ukr.net, https://orcid.org/0000-0001-9439-1919

Кіпіоро Інна Миколаївна кандидат економічних наук, доцент кафедри управління персоналом та економіки праці, Центральноукраїнський інститут Приватного акціонерного товариства «Вищий навчальний заклад «Міжрегіональна академія управлення персоналом», вул. Варшавська, 2, м. Кропивницький, 25026, тел.: (097) 714-05-16, e-mail: innuscha@ukr.net, https://orcid.org/0000-0002-8482-1265

\title{
АЛГОРИТМ КОРИГУВАННЯ ЗМІСТУ ПСИХОЛОГІЧНИХ, ПРАВОВИХ, ЕКОНОМІЧНИХ ДИСЦИПЛІН В КОНТЕКСТІ ФОРМУВАННЯ ПІДПРЕМНИЦЬКОЇ КУЛЬТУРИ
}

Анотація. У статті розкрито такі актуальні питання бізнес-дидактики (підприємницької педагогіки) як формування підприємницької культури особистості, подано алгоритм відповідного коригування змісту навчальних дисциплін.

3 приводу змісту категорії підприємницької дидактики нині точаться гострі дискусії, у ході яких вимальовується аргументована позиція, що цей термін позначає всі форми освіти і підготовки, як офіційні, так і неофіційні, у тому числі й навчання на виробництві, які сприяють розвитку духу підприємництва i вчать реальній чи майбутній комерційній діяльності. Це визначення спирається на положення Європейської хартії для малого бізнесу. Його сутність полягає в тому, що разом 3 важливістю навчання безпосередньо на робочому місці, підкреслюється особлива роль розвитку підприємницького типу мислення й бізнес-навичок в суб'єктів педагогічного процесу початкової, середньої і вищої ланок освіти. У зв’язку з цим виконуються відповідні наукові дослідження й технічні розробки. По суті, це положення хартії стосується людських 
ресурсів, спрямованих на створення структури неперервного навчання підприємництву і $є$ орієнтиром для подальшого розвитку освітньої політики. Важливими завданнями є: відбір ключових навичок підприємництва, які мають бути виписані в навчальних планах i програмах навчальних дисциплін; зосередження уваги на навчанні підприємництву, - маючи на меті при цьому заміну вузької бізнес-орієнтації на завдання розвитку типу особистості підприємця й формуванню в неї відповідного рівня «ефективної» підприємницької поведінки. Зокрема, для виконання цього завдання висунуто політичну ініціативу $\mathrm{CC}$ щодо формування «ключових навичок навчатися протягом усього життя», згідно 3 якою підприємництво $є$ «життєвою навичкою» $\mathrm{i}$ визначається як здатність людини втілювати ідеї в дії. Цією ініціативою в підприємництві задекларовано творчий підхід, новаторство, розумний ризик, а також уміння планувати проекти та керувати ними. I хоча в цьому визначенні замало конкретики, із нього все-таки випливає, що компетентність підприємця містить низку навичок та алгоритмів поведінки (наприклад, здатність до розв'язання проблем, планування, командної роботи, творчості й ухвалення ризикованих рішень), які в сукупності формують основу характеру й особистості підприємця. Яким чином окреслені навички й особливості поведінки розвиватимуться в умовах систематизованого процесу навчання ще тільки належить вирішити. Отже, нині активно розгортаються теоретичні й практичні ідеї підприємницької педагогіки. Їх перспективність розкриває широкі можливості для подальшого соціального та економічного розвитку суспільства.

Ключові слова: бізнес-дидактика, навчальна програма, психологія, економіка, право, підприємницька культура, формування

Fedorov Oleksandr Volodymyrovych Candidate of Pedagogic Sciences (Ph. D), Associate Professor at the Department of the Humanities and Natural and Economic Sciences, Central Ukrainian Institute of the Interregional Academi of Personnel Management, Varshavs'ka St., 2, Kropyvnyts'kyj, 25026, tel.: (095) 901-85-74, e-mail: fov.1961@ukr.net, https://orcid.org/0000-0002-0458-3587

Podolyaka Anatoly Mykolaiovych Doctor of Law Science, Professor, Department of Law, Central Ukrainian Institute of PJSC "Interregional Academy of Personnel Management", Varshavs'ka St., 2, Kropyvnyts'kyj, 25026, tel.: (0522) 27-50-07, e-mail: tdp413@ukr.net, https://orcid.org/0000-0001-9439-1919

Kipioro Inna Mikolayivna $\mathrm{PhD}$ in Economics, Associate Professor of Personnel Management and Labor Economics of the Department of Personnel Management and Labor Economics of Central Ukrainian Institute Private Joint-Stock Company «Higher Educational Institution "Interregional Academy of Personnel Management"», Varshavs'ka St., 2, Kropyvnyts'kyj, 25026, tel.: (097) 714-05-16, e-mail: innuscha@ukr.net,https://orcid.org/0000-0002-8482-1265 


\section{ALGORITHM OF ADJUSTMENT OF THE CONTENT OF PSYCHOLOGICAL, LEGAL, ECONOMIC DISCIPLINES IN THE CONTEXT OF FORMATION OF ENTREPRENEURIAL CULTURE}

Abstract. The article reveals such topical issues of business didactics (entrepreneurial pedagogy) as the formation of entrepreneurial culture of the individual, presents an algorithm for appropriate adjustment of the content of academic disciplines.

The content of the category of entrepreneurial didactics is currently hotly debated, during which it is argued that this term refers to all forms of education and training, both formal and informal, including training in the workplace, which promotes entrepreneurship and teaches. actual or future commercial activity. This definition is based on the provisions of the European Charter for Small Enterprises. Its essence is that along with the importance of learning directly in the workplace, the special role of the development of entrepreneurial thinking and business skills in the pedagogical process of primary, secondary and higher education is emphasized. Appropriate research and development is being carried out in this regard. In essence, this provision of the Charter concerns human resources aimed at creating a structure of lifelong learning for entrepreneurship and is a guide for further development of educational policy. Important tasks are: selection of key business skills to be written in the curricula and programs of academic disciplines; focusing on entrepreneurship education, with the aim of replacing the narrow business orientation with the task of developing the type of entrepreneurial personality and forming an appropriate level of "effective" entrepreneurial behavior. In particular, to meet this challenge, the EU has launched a policy initiative to develop "key lifelong learning skills", according to which entrepreneurship is a "life skill" and is defined as a person's ability to put ideas into action. This initiative has declared creativity, innovation, reasonable risk, as well as the ability to plan and manage projects. And although this definition lacks specificity, it still follows that the competence of the entrepreneur includes a number of skills and behavioral algorithms (eg, ability to solve problems, planning, teamwork, creativity and risk-taking), which together form the basis of the character and personality of the entrepreneur. How the outlined skills and behaviors will develop in a systematic learning process remains to be seen. Thus, theoretical and practical ideas of entrepreneurial pedagogy are currently being actively developed. Their prospects open wide opportunities for further social and economic development of society.

Keywords: business didactics, curriculum, psychology, economics, law, business culture, formation.

Постановка проблеми. У педагогіці категорія «формування» розглядається як один із видів розвитку особистості: зміна (удосконалення) динамічної функціональної структури особистості, головним чином іiі змісту

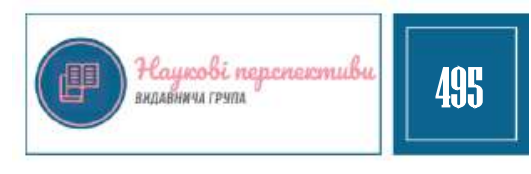


під впливом зовнішніх чинників. Отже, i закономірних змін об'єкта від простого до складного, від нижчого до вищого і як результат переходу до нового, досконалішого якісного стану. Цей процес розгортається у часі як закономірна зміна різних станів, послідовність яких визначена їх внутрішньою структурою і тими можливими перетвореннями, які містяться в цій структурі у формі інтенціональності (внутрішньої спрямованості на певну ціль).

Грунтуючись на цьому, формування підприємницької культури майбутнього фахівця має базуватися на стрункій цілеобгрунтованій системі організації навчально-виховного процесу, описаній у єдиних для будь-якої продуктивної діяльності поняттях і структурі.

Актуальність проблеми обумовлена необхідністю якісної підготовки висококваліфікованих, творчо розвинених, конкурентноспроможних та мобільних фахівців, здатних на конструктивних засадах кардинально змінити соціальноекономічну систему, на чому наголошується у Національній доктрині розвитку освіти України у XXI столітті.

Рушієм таких перетворень постає «культурне підприємництво», функціонально призначене для збагачення соціокультурного простору, саморозвитку, самоактуалізації, самореалізації особистості.

Аналіз останніх досліджень i публікацій. Важливих аспектів коригування навчальних програм 3 метою формування підприємницької культури майбутнього фахівця торкаються у своїх публікаціях такі вітчизняні та зарубіжні автори як В. Полянко, А. Круглянко, М. Курбатова, М. Магура, Г. Ковальчук, Н. Бутенко, М. Артюшина Г. Захарчин [1 - 5] та інші. Однак питання розробки алгоритму коригування змісту психологічних, правових, економічних навчальних дисциплін для формування підприємницької культури особистості поки що не систематизовані.

Метою статті $є$ пропозиція алгоритму коригування змісту психологічних, правових, економічних навчальних дисциплін для формування підприємницької культури особистості.

Виклад основного матеріалу. На сучасному етапі розвитку вищої освіти активізуються пошуки варіантів моделювання змісту навчальних програм, спрямованих на отримання студентами високого рівня кваліфікацій, які дають змогу їм після завершення навчання задовольнити запити ринку праці. Один із таких варіантів $є$ модульний підхід до їх проектування.

У більшості вищих навчальних закладах європейських країн навчальна програма за своєю конструкцією передбачає такі обов’язкові складники: стандарт національної компетенції (national competenz standarts); оціночні директиви й матеріали (assessment guidelines); національну кваліфікацію (national qualifications); навчальну стратегію (learning strategy); професійнорозвивальний матеріал (professional development vaterials). 3 огляду на це, процес моделювання змісту навчальних програм соціально-економічної та професійноорієнтованої підготовки майбутніх фахівців вимагає розробки принципів, 
відповідних модульно-компетентнісному та культурологічному підходів.

Отже, пропонуємо уніфіковані принципи коригування навчальних програм у межах підприємницької дидактики:

1) порівняльний - зіставлення спрямованості програм традиційного навчання $з$ вимогами бізнес-дидактики;

2) проективний - чітке визначення завдань і мети навчання, адекватних критеріям оцінки, які мають бути досягнуті; деталізовано поставлені завдання, які гарантують вимірюваність і стійкість результатів навчання;

3) модульного структурування програми дисципліни, яким передбачено, що кожний змістовий модуль забезпечуватиме приріст підприємницької культури студента;

4) цілеспрямованого формування підприємницької культури, що передбачає визначення дидактичної мети, сформульованої відповідно до функцій майбутньої професійної діяльності;

5) варіативності змісту програми й строків навчання - гнучкі вимоги 3 використанням освітнього консиліуму стосовно вибору індивідуалізованих заходів, що гарантує досягнення заданого результату відповідно до освітнього темпу кожного студента;

6) дидактичного відбору змісту навчальних модулів, які слугують основою для формування підприємницької культури: гуманізму, науковості, послідовності, системності, природовідповідності, професійної спрямованості, креативності, інноваційності, достатності, оптимізації, доступності, варіативності, інтегративності;

7) відносної самостійності й взаємозв’язку елементів навчального модуля в організації його змісту - лінійної, концентричної, спіральної, комбінованої;

8) конфігурування майбутньої професійної діяльності та міри підготовленості до неї;

9) конкретизації та синтезу знань, передбачених програмою дисципліни;

10) оптимального поєднання традиційних і підприємницьких технологій навчання, закладених у зміст навчальної дисципліни;

11) стандартизації в оцінюванні результатів навчання, що грунтується на однозначних критеріях оцінки досягнень студентів.

Згадані принципи мають організаційну спрямованість у процесі коригування навчальної програми.

Щоб перейти до практичних дій з коригування змісту дисциплін соціальноекономічної та професійно-орієнтованої підготовки майбутніх фахівців, пропонуємо попередньо скласти схему уніфікованої підприємницько-зорієнтованої програми (рис. 1). 


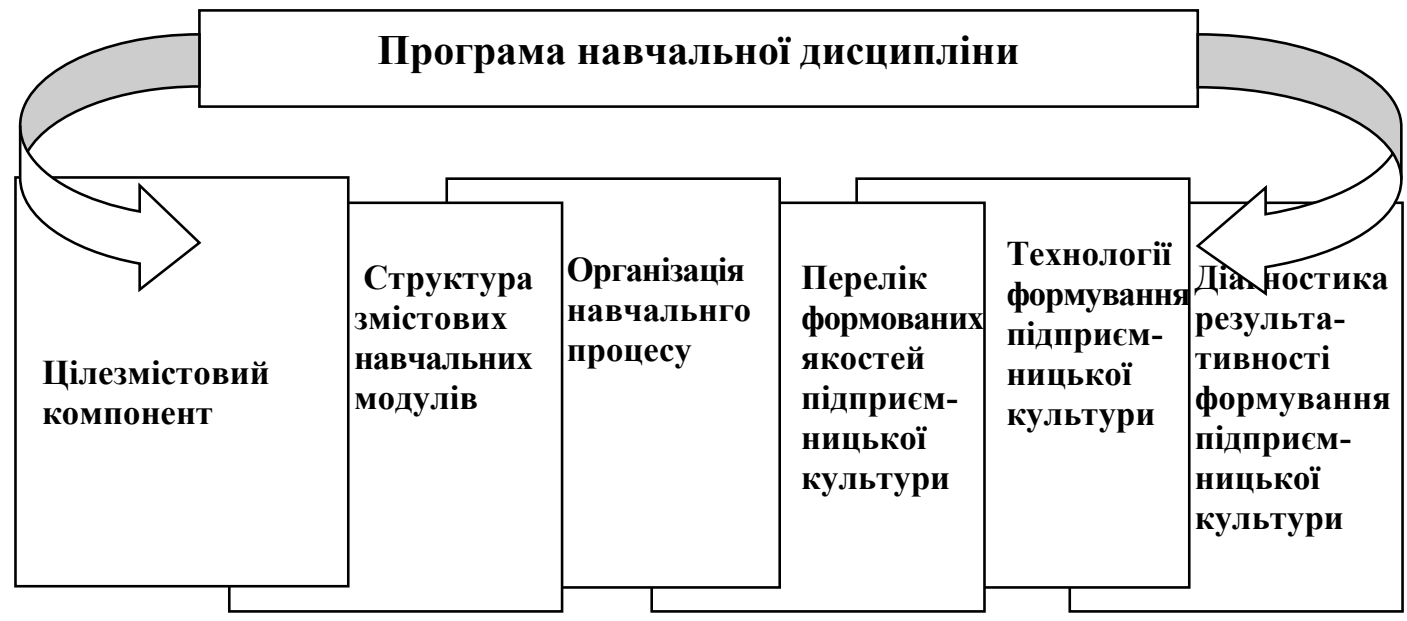

Рис. 1. Схема уніфікованої модульної підприємницько-зорієнтованої програми дисичиліни.

У процесі конструювання підприємницько-зорієнтованої програми дисципліни доцільно скористатися комплексно-цільовим підходом. Його сутність полягає в побудові цілезмістового компонента, який складається 3 комплексно-дидактичної мети, інтегративних і часткових дидактичних цілей.

Послідовність побудови цілезмістового складника така:

1) визначення комплексної дидактичної мети модульної підприємницько-зорієнтованої програми дисципліни;

2) вичленування 3 комплексної дидактичної мети інтегративних дидактичних цілей і формування на цій основі змістових модулів, кожному 3 яких відповідає своя інтегративна дидактична мета;

3) поділ кожної інтегративної дидактичної мети на часткові дидактичні цілі відповідно до найбільших блоків змістового модуля й визначення на цій основі навчальних компонентів.

Окреслену послідовність можна репрезентувати як ієрархію цілей:

- $\quad$ комплексна дидактична мета (КДМ) для всієї модульної програми;

-інтегративна дидактична мета (ІДМ) для змістових модулів (3М) програми;

- часткові дидактичні цілі (ЧДЦ) - для побудови навчальних компонентів (НК) (рис. 2).

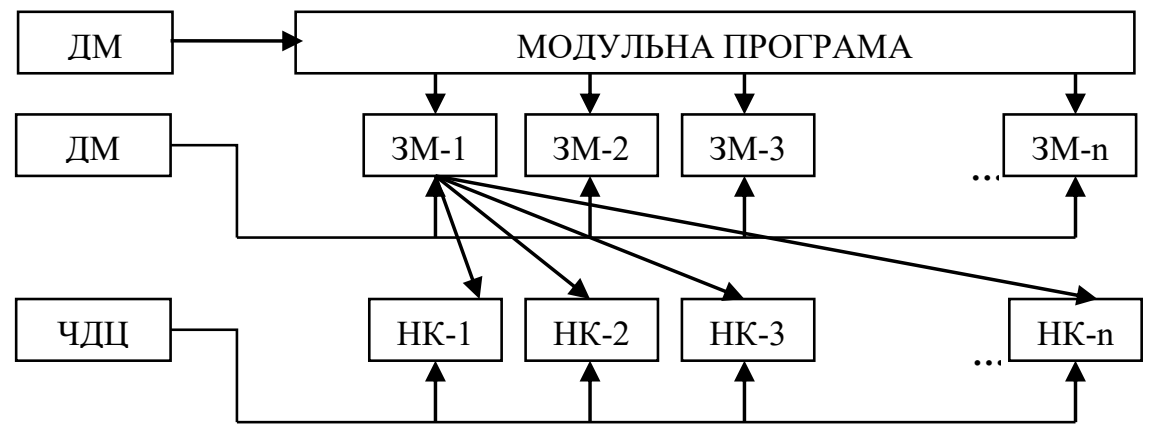

Рис. 2. Схема изілезміствого компонента модульної програми. 
Як видно з рис. 2, кожен змістовий модуль (3М-1, 3М-2,...3М-n) складається 3 навчальних компонентів (НК-1, НК-2,...НК-n), блоку їхньої інформаційної забезпеченості (I3). На свою чергу, кожен навчальний компонент доповнюється переліком використовуваних організаційних форм навчання (ОФН), а кожен змістовий модуль завершується двома блоками: КПКТ - картою підприємницької культури і технологій, а також таблицею результативності іï формування (ТРФПК) (рис. 3).

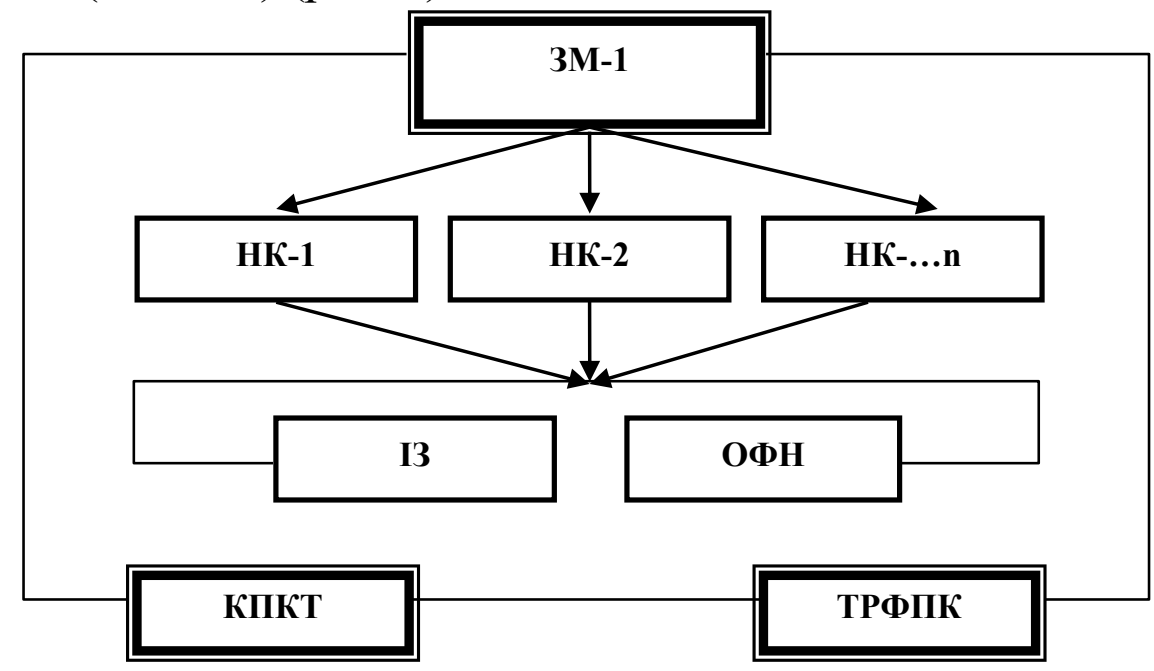

Pис. 3. Граф-схема змістового навчального модуля підприємницькозоріснтованої програми

Протягом останніх років конструювання у вітчизняній педагогіці стало співвідноситись як із процедурами нормативно-алгоритмічного характеру, так і $з$ прийомами креативної діяльності викладача. Тому конструювання навчального змістового модуля треба розпочинати з його задуму, що містить у собі відбір матеріалу й логічну схему розгортання навчально-виховного процесу; співвіднесення дидактичного матеріалу 3 рівнем пізнавального й життєвого досвіду суб'єктів навчання: оцінювання матеріалу 3 позиції того, кого навчають, та його методичне оформлення.

Конструювання змісту навчального модуля передбачає постановку конкретних завдань у його операційній частині, підставою для чого слугує «характер діяльності студента» (репродуктивний, частково-пошуковий, творчий).

Отже, основними елементами навчального модуля є:

-інформаційна (пізнавальна) частина, що являє собою навчальну інформацію, згорнуту в навчальні елементи на основі низки принципів і відібрану на основі контекстного підходу;

-операційна (виконавська) частина, репрезентована у формі практичних завдань різної складності з комплектами орієнтовної основи діяльності, а також набору практичних робіт із методичними вказівками до них;

-контрольно-оцінювальна частина, що складається із завдань для самоконтролю й тестів різних рівнів складності; 
-методична частина, що містить у собі опис методик проведення занять із урахуванням різного рівня складності навчальної діяльності студентів.

У відборі дидактичних компонентів модуля необхідно керуватися такими принципами:

1. єдності і протилежності логіки й науки навчальної дисципліни (оптимальне й економне розгортання матеріалу);

2. природовідповідного, гармонійного й культурного розвитку особистості (виховне спрямування матеріалу);

3. розвивального навчання (проблемний виклад матеріалу й творчий характер завдань);

4. вв'язку теорії 3 практикою (галузі практичного використання знань);

5. свідомості в засвоєнні знань (рефлексія навчального досвіду);

6. взаємопов'язаного викладення навчального матеріалу (міжпредметні зв'язки);

7. універсалізації діяльності (перенесення способів діяльності з різних галузей).

Відібравши навчальні компоненти кожного змістового модуля, потрібно конкретизувати їх за характером інформаційної забезпеченості, яка передбачає використання різних способів одержання інформації - від викладача, від студента, із літератури, технічних засобів навчання, Інтернету та інших джерел.

За вимогами Болонських домовленостей інформаційні й навчальнометодичні матеріали модульної програми дисципліни мають бути подані у формі електронних варіантів, які найприйнятніші для масового тиражування засобами Інтернет-технологій. Серед них обов'язково мають бути: повний електронний варіант програми дисципліни, лекції, практикуми, задачники, комп'ютерні тренінгові програми, тести, наочність тощо.

У структурі модульної програми до блоку організаційних форм навчання мають входити різні типи лекційних (лекція-бесіда, лекція-діалог, лекція з розбором конкретних підприємницьких ситуацій, лекція 3 помилками та ін.) і практичних занять (семінари, колоквіуми, експрес-опитування, письмові контрольні роботи, ділові ігри або перемовини, конкурси, змагання; виконання вправ, тестів тощо), самостійна робота студентів (навчальна, позааудиторна).

Картою підприємницької культури і технологій передбачено визначення переліку професійних якостей підприємця, які необхідно прогнозовано формувати під час реалізації конкретного змістового модуля, а також відповідного технологічного ресурсу. Для цього складається таблиця, у якій все це фіксується. 
Таблиия 1

Карта підприсмницької культури і технологій

\begin{tabular}{|c|c|c|}
\hline \multicolumn{2}{|c|}{ 3М-I } \\
\hline № НК & $\begin{array}{c}\text { Перелік професійних якостей } \\
\text { дизайнера-бізнесмена }\end{array}$ & Технології формування \\
\hline HК-1 & $\begin{array}{c}\text { предметно-теоретичні знання, ділова } \\
\text { комунікативність, підприємницькі та проектно- } \\
\text { творчі здібності }\end{array}$ & $\begin{array}{l}\text { малих груп, } \\
\text { портфоліо, ігрові, кейс- } \\
\text { стаді, диспут }\end{array}$ \\
\hline HК-2 & & \\
\hline HК-3 & & \\
\hline
\end{tabular}

Таблицею результативності формування підприємницької культури передбачено комплексну діагностику іiї сформованості за переліком виконаних завдань кожного навчального компонента й рейтингом оцінки якості їхнього виконання конкретним студентом (табл. 2).

У процесі діагностики підприємницької культури студентів доцільно дотримуватися таких принципів:

- компетентнісний вимір якості навчання i, як наслідок, професійно спрямований та підприємницький характер завдань;

- практичний характер завдань (добираються 3 практичної діяльності бізнес-діяльності); короткотривалість виконання завдань (трудомісткість завдання не повинна перевищувати $6-8$ академічних годин, тобто одного дня занять).

Основними засобами проведення діагностичних процедур мають бути: розроблення контрольно-вимірювальних матеріалів для ідентифікації рівня сформованості підприємницької культури (проміжний контроль) та випробовування очікуваного результату навчання (підсумковий контроль). 
Таблиия 2

Таблиця результативності формування підприємницької культури студентів за кожним змістовим модулем програми

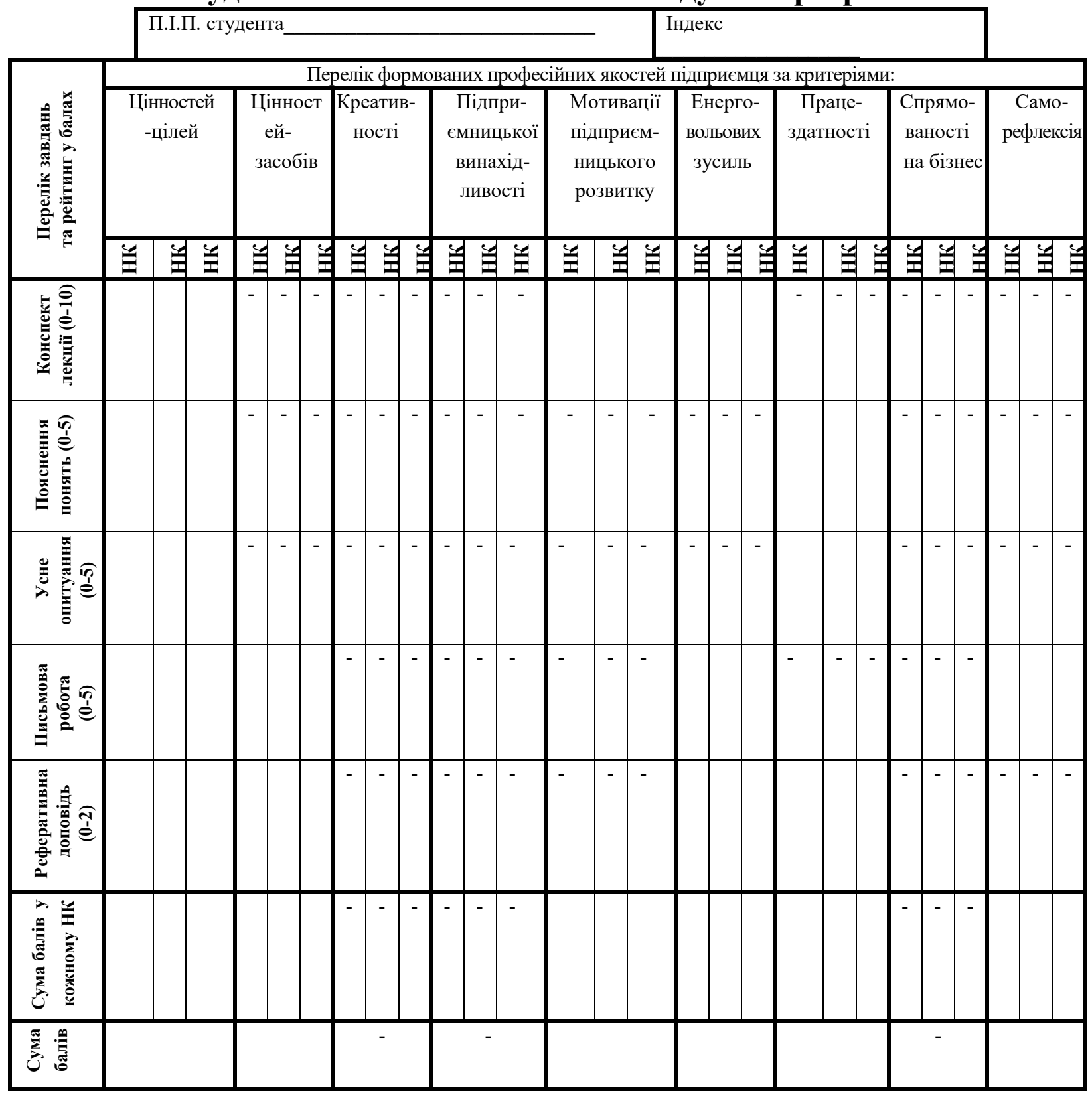

Необхідно також проводити проміжний діагностичний контроль, призначений для перевірки таких видів діяльності студента: відтворення уявлень і знань у модельованих стандартних ситуаціях підприємництва, узятих з реальної професійної діяльності; використання знань, умінь для ухвалення рішень та синтезу нових знань і вмінь.

Висновки. Незважаючи на величезну увагу, яка в системах освіти розвинених країн приділяється підприємництву, досі немає чіткого визначення термінів «підприємницька педагогіка» та «бізнес-дидактика». Частково це пояснюється тим, що все-таки не визначено, на якому рівні освітньої системи 
потрібно починати навчання підприємництву, яка його природа, які дисципліни передбачено вивчати і хто їх має викладати. Через це не визначено й цілі навчання підприємництву в процесі підготовки майбутніх фахівців різного профілю. Також виникають додаткові труднощі, пов’язані з відсутністю загальноприйнятих принципів, моделей і теорій освіти в галузі підприємництва. Це - бар'єри на шляху до узгодженого розуміння й визначення педагогічних концепцій, понять, змісту, форм i методів навчання підприємництву, i, особливо, формування підприємницької культури.

Підприємницька культура безпосередньо пов'язана, по-перше, 3 розумінням сутності підприємницької діяльності та місця в суспільстві підприємців як соціальної групи; по-друге, з функціями, що характеризують 3'ясування місця і ролі в суспільному житті підприємництва дає нам підстави твердити, що останнє в цілому (як феномен) пронизане системою культурних детермінант. Системоутворюючим чинником i для підприємництва як діяльності, і для підприємців як соціальної верстви є культурний зміст. Слід наголосити, що цей зміст, за П. Бурдьє (котрий обгрунтував існування трьох різновидів суспільного капіталу: економічного, культурного і символічного) $\epsilon$ «культурним капіталом», який надає певному соціальному статусові легітимності. «Культурний капітал» виступає у формі культури підприємницької діяльності, підприємницької культури - інтеграційного чинника ефективності ділової активності і бізнесу в цілому.

У сучасній економічній літературі виокремлено дві провідні тенденції навчання підприємництву. У межах першої тенденції воно розглядається, насамперед, як сфера, що підвідомча світу бізнесу. У цих умовах державні й приватні вищі навчальні заклади є основними освітніми інститутами, котрі своєю головною метою діяльності ставлять забезпечення майбутніх підприємців спеціальними знаннями і навичками, необхідними для заснування й розвитку власного бізнесу. Друга, сучасніша тенденція, пов'язується 3 навчанням підприємництву, як розвитку комплексу професійних якостей та рис характеру особистості підприємця.

Підприємницька культура безпосередньо пов'язана, по-перше, 3 розумінням сутності підприємницької діяльності та місця в суспільстві підприємців як соціальної групи; по-друге, з функціями, що характеризують підприємницьку діяльність. Якщо говорити про першу зі складових, то вона спирається на те, що сутнісно поєднує підприємництво та суспільство, те, що є вищим від простої дії економічного механізму, оскільки на основі культурної взаємодії зростає не тільки культурна цілісність, але й формується принципово інше ставлення до самого підприємництва. Це, у свою чергу, породжує потенціал підприємництва, істотно підвищуючи конкурентоздатність підприємницької спільноти.

Іншим значущим моментом, що характеризує соціокультурну взаємодію підприємництва та суспільства, $\epsilon$ сконцентрована у самій сутності 
підприємництва здатність до відтворення інноваційного потенціалу суспільства. Таким чином, підприємницька культура сприяє відтворенню в суспільстві потенціалу його розвитку і не тільки економічного. Йдеться про соціокультурний потенціал розвитку.

Біля витоків виникнення підприємницької культури - ідея свободи волі людини. Культура не може 3'явитися без свободи як невід'ємної духовної потенції людини. Свобода ж визначається ступенем пізнання людьми об'єктивних процесів у природі і суспільстві, розширенням реальних можливостей для застосування своїх здібностей та ініціатив.

\section{Лimepamypa:}

1. Захарчин Г. М. Основи підприємництва : [навч. посібник]. К. : Знання, 2008. 437 с.

2. Ковальчук Г. О. Активізація навчання в економічній освіті : [навч. посібник] / Г. О. Ковальчук. К. : КНЕУ, 2005. 298 с.

3. Ковальчук Г. О. Тренінгові технології навчання з економічних дисциплін : [навч. посібник] / Ковальчук Г. О., Бутенко Н. Ю., Артюшина М. В. та ін. К. : КНЕУ, 2006. 320 с.

4. Курбатова М. Б. Обучение персонала как конкурентное преимущество / М. Б. Курбатова, М. И. Магура. Управление персоналом. 2004. № 11-12 (98). С. 35 - 41.

5. Полянко В. В. Основи підприємництва : [навч. посібник] / В. В. Полянко, А. В. Круглянко. К. : Дакор, КНТ, 2008. 176 с.

\section{References:}

1. Zakharchyn H.M. Osnovy pidpryiemnytstva [Fundamentals of Entrepreneurship: [textbook manual]. Kyiv: Znannia, 2008. 437 p. [in Ukrainian].

2. Kovalchuk H.O. Aktuvizatsia navchannia v ekonomichnii osviti [Activation of learning in economic education]: [textbook manual]. Kyiv: KNEU, 2005. 298 s. [in Ukrainian].

3. Kovalchuk H.O. Training technologies for teaching economic disciplines: [textbook manual] / Kovalchuk H.O., Butenko N.Yu., Artiushyna M.V. and others. Kyiv: KNEU, 2006. 320 p. [in Ukrainian].

4. Kurbatova M.B. Obuchienie personala kak konkurientnoie prieimushchiestvo [Staff training as a competitive advantage] / M.B. Kurbatova, M.I. Magura. Upravlienie personalom [Personnel management]. 2004. № $11 \square 12$ (98). Pp. $35 \square$ - 41. [in Russian].

5. Polianko V.V. Osnovy pidpryiemnytstva [Fundamentals of Entrepreneurship: textbook manual] / V.V. Polianko, A.V. Kruglianko]. Kyiv: Dakor, KNT, 2008. 176 p. [in Ukrainian]. 